\title{
Evaluating Some Insecticides for Controlling the Sunn Pest Eurygaster spp. Puton (Hemiptera: Scutelleridae) under Field Conditions
}

\author{
Mohammed Zaidan Khalaf ${ }^{1}$, Hussain Fadhil Alrubeai ${ }^{1}$, Ali Abdulla Sultan ${ }^{2}$ and Ahmad Mehdi Abdulkareem ${ }^{3}$ \\ 1. Integrated Pest Control Research Center, Directorate of Agricultural Research, Ministry of Science \& Technology, Baghdad \\ 00964, Iraq \\ 2. Directorate of Plant Protection, Ministry of Agriculture, Baghdad 00964, Iraq \\ 3. College of Agriculture, Baghdad University, Baghdad 00964, Iraq
}

\begin{abstract}
The sunn pest Eurygaster integriceps is the most important insect of cereals in Iraq and other countries. In this study, the field efficacy of 10 different kinds of insecticides with various mode of action was evaluated against sunn pest E. integriceps infested wheat on field at middle of Iraq. Experiments were conducted in 11 wheat fields with each field 0.5 ha, located in the middle of Iraq (Wasit and Salahudain governorates) during season 2015-2016. The wheat fields contained common varieties of wheat planted in Iraq. The population density of the pest was at its highest level (start of April 2015) of mostly nymphs, adults and eggs. The results indicated that the recommended dose for each insecticide used showed high efficacy (80.1\%-93.8\%) in reducing number of $E$. integriceps adults after one week of treatment, reaching 0.2-0.8 insects $/ \mathrm{m}^{2}$ compared to 3.6 insects $/ \mathrm{m}^{2}$ in the control treatment. These results will assist the control program of this pest and in implementing pest management practices to reduce resistance development chances.
\end{abstract}

Key words: Efficacy, insecticides, sunn pest, Eurygaster spp., wheat.

\section{Introduction}

The sunn pest Eurygaster integriceps Puton (Hemiptera: Scutelleridae) is one of the most important pests of wheat and barley in West and Central Asia, including Iran, Turkey, Iraq, and in the Eastern Europe [1, 2]. E. integriceps attacks and feeds on both the vegetative stages of the plant and maturing grain. Bouhssini et al. [3] have pointed that the transmission of toxic enzymes into maturing grain can reduce the milling quality, rendering the flour useless for human consumption [2, 4]. Feeding on vegetative stages can cause withering and dead hearts, leading to a reduction in yield. In Iraq, E. integriceps represents continuous annual thread, especially in the north

Corresponding author: Mohammed Zaidan Khalaf, professor, research fields: entomology, integrated pest management of insect pests. region, and was recorded in wheat fields north of the capital (Baghdad) during the nineteenth of last century. During season of 2000-2001, infestations were spread to cover new ecological areas, such as most of the middle of Iraq. The only strategy applied for the control depends solely upon spraying chemical insecticides. Turkish governments have conducted sunn pest management programs, mainly based on chemical control since 1927 [5, 6] and evaluated six insecticides for control overwintered adults of sunn pest under field conditions in Turkey. Mermithid nematode, Hexamermis eurygasteri n. sp. was used as a biological control agent in an integrated control program of the sunn pest in Turkey [7]. Turkish government has been changing the sunn pest overwintering adult control policy by wheat growers after shifting from aerial spray to ground application. Therefore, control application made according to the 
plant protection technical guidelines would improve the effect of the struggles to reduce the economic losses in wheat production and develop control application [8, 9] used the entomopathogenic fungus Beauveria bassiana, an oil-based formulation to control the sunn pest E. integriceps in wheat field.

The present investigation was conducted to evaluate field efficacies of some insecticides of different mode of action to be used in the control campaign of the sunn pest Eurygaster spp..

\section{Materials and Methods}

Experiments were conducted in 11 wheat fields with each field 0.5 ha located in the middle of Iraq (Wasit and Salahudain governorates) during 2015-2016. The population density of the pest was at its highest level (start of April 2015) of mostly nymphs, adults and eggs. Ten insecticides with different mode of action were used in the recommended doses to spray the wheat fields as was shown in Table 1 [10]. Selecting more than one brand of alphacypermethrin was due to the registration of all these brands by the national committee for pesticides registration and approval and to compare between products of the same active ingredient. Each treatment contained three replicates $\left(1,000 \mathrm{~m}^{2}\right.$ per replicate). Numbers of nymphs and adults Eurygaster spp. present per $1 \mathrm{~m}^{2}$ were counted carefully directly on the wheat plants of $10 \mathrm{~m}^{2}$ chosen randomly per each replicate before and after treatments with one, three and seven days (one week) taken from different parts of plant. Two sprayers of 100 L EC and 2 L ULV Guarany were used for all replicates from up to down to ensure exposing the pest individuals to the insecticides tested.

Complete randomized block design was used in conducting all experiments. Genstat program and LSD (0.05 level) were implied in statistical analysis and determined the significance between insecticides efficacies. Henderson-Tilton's formula [11] was used to calculate corrected insecticides efficacies (measured as $a \%$ ) on nymphs and adults Eurygaster spp. mortality.

\section{Results and Discussion}

The results showed that recommended doses of the tested insecticides (as in Table 1) gave high efficacies in reduction of adult and nymph numbers of $E$. integriceps on wheat plants. Results in Table 2 indicated the significant reduction in the average number of nymph and adults per $1 \mathrm{~m}^{2}(0.3-1.6)$ individuals after three days of treatment in comparison with 3.4 individuals in the control of EC treatment. The reduction in number of live adults after one week

Table 1 Tested insecticides used in the experiments of measuring their efficacies on sunn pest $E$. integriceps.

\begin{tabular}{|c|c|c|c|c|c|}
\hline $\begin{array}{l}\text { Insecticide } \\
\text { brand name }\end{array}$ & Company & $\begin{array}{l}\text { Recommended } \\
\text { concentration }\end{array}$ & $\begin{array}{l}\text { Mode of action according to } \\
\text { IRAC } 2016 \text { [10] }\end{array}$ & $\begin{array}{l}\text { Active ingredients and } \\
\text { concentration }\end{array}$ & $\begin{array}{l}\text { Chemical } \\
\text { sub-group }\end{array}$ \\
\hline Desis & Bayer & 75 mL/100 L & Sodium channel modulators & Deltamethrin 2.5 g/L EC & 3A, pyrethroid \\
\hline Megaalpha & Meghamani & $30 \mathrm{~mL} / 100 \mathrm{~L}$ & Sodium channel modulators & Alphacypermethrin 10\% EC & 3A \\
\hline Alphasin & Sineria & 30-40 mL/100 L & Sodium channel modulators & Alphacypermethrin 10\% EC & 3A \\
\hline Levo & Seneria & 4 L/ha ULV & $\begin{array}{l}\text { Uncertain mode of action } \\
\text { unknown }\end{array}$ & Oxymatrin & $\begin{array}{l}\text { unknown, plant } \\
\text { extract }\end{array}$ \\
\hline Flash & Tagros & 35-40 mL/100 L & Sodium channel modulators & Alphacypermethrin 10\% EC & 3A \\
\hline Matrixin plus & Russell IPM & $60 \mathrm{~mL} / 100 \mathrm{~L}$ & $\begin{array}{l}\text { Glutamate-gated chloride } \\
\text { channel allosteric modulators }\end{array}$ & $\begin{array}{l}\text { Abamactein }+ \text { oxymatrin and } \\
\text { unknown, plant extract }\end{array}$ & 6 \\
\hline Golan & Seneria & 75-100 mL/100 L & $\begin{array}{l}\text { Nicotinic acetylcholine receptor } \\
\text { (nAChR) allosteric modulators }\end{array}$ & Acitamiprid 20 SL & $\begin{array}{l}\text { 4A, } \\
\text { neonicotinoids }\end{array}$ \\
\hline Talstar & FMC, USA & $100-150 \mathrm{~mL} / 100 \mathrm{~L}$ & Sodium channel modulators & Bifenthrin 10\% EC & 3A \\
\hline Bestoy & FMC, USA & $150-200 \mathrm{~mL} / 100 \mathrm{~L}$ & Sodium channel modulators & Alphacypermethrin 10\% EC & $3 \mathrm{~A}$ \\
\hline Bestseller & FMC, USA & $100-150 \mathrm{~mL} / 100 \mathrm{~L}$ & Sodium channel modulators & Alphacypermethrin 5\% EC & 3A \\
\hline
\end{tabular}


of treatment reached 0.2-0.8 nymph or adults $/ \mathrm{m}^{2}$ and 3.6 nymph or adults $/ \mathrm{m}^{2}$ in the control treatment. Significant differences were found between results of some tested insecticides and that of the controls and for all periods. Insecticides efficacies after one week

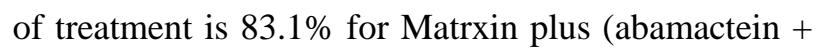
oxymatrixin) as glutamate-gated chloride channel allosteric modulators and $98.4 \%$ for Levo ULV (a. i. Oxymatrin, is one of many quinolizidine alkaloid compounds extracted from the root of Sophora flavescens, a Chinese herb) [6]. This comparison indicated that using insecticides with acetamiprid (SL, soluble concentrate), chlorpyrifosethyl (EC, suspension concentrate), lambda-cyhalothrin (CS, sodium channel modulators suspension), monocrotophos (SC, suspension concentrate), thiacloprid (SC) and zeta-cypermethrin (EC) as active ingredient gave high efficacies in controlling $E$. integriceps adults and reduced subsequent egg laying and the appearance of nymphs in the trial area in Turkey.
The low mortality rate compared to the rate (93.8\%) obtained during recent investigation could be attributed to the difference of the source and dose rate, in addition to the difficulty of counted adults. The results of treatment of nymphs and adults indicated that spraying with the recommended doses of the tested insecticides (Levo, Golan, Desis, Flash, Telstar, Bestoy and Bestseller) showed high efficacies in nymphs and adults mortality. The results in Table 2 showed high effect on nymphs and adults after one week of treatment ranged from $81.3 \%$ to $94.1 \%$ for Bestoy (alphacypermethrin as sodium channel modulators) and Golan (acitamiprid as nAChR allosteric modulators), respectively. Mortalities were ranged between $84.0 \%-87.2 \%$ for Matrxin (abamactein + oxymatrixin) glutamate-gated chloride channel allosteric, Alphasin (alphacypermethrin, 10\% EC) sodium channel modulators and Talstar (bifenthrin 10\% EC) sodium channel modulators.

The result also showed that insecticide Flash (35-40 $\mathrm{mL} / 100 \mathrm{~L}$ ) has the highest efficacy between brands

Table 2 Field efficacies of some insecticides in controlling sunn pest $E$. integriceps in wheat fields.

\begin{tabular}{|c|c|c|c|c|c|c|c|c|c|c|}
\hline \multirow{3}{*}{ Treatment } & \multicolumn{10}{|c|}{ Average insect number of sunn pest per $1 \mathrm{~m}^{2}$, mortality (\%) and efficacy (\%) before and after } \\
\hline & \multirow{2}{*}{$\begin{array}{l}\begin{array}{l}\text { Before } \\
\text { treatment }\end{array} \\
\text { Insect }\end{array}$} & \multicolumn{3}{|c|}{ One day after } & \multicolumn{3}{|c|}{ Three days } & \multicolumn{3}{|c|}{ One week } \\
\hline & & Insect & $\begin{array}{l}\text { Mortality } \\
(\%)\end{array}$ & $\begin{array}{l}\text { Efficacy } \\
\text { (\%) }\end{array}$ & Insect & $\begin{array}{l}\text { Mortality } \\
(\%)\end{array}$ & $\begin{array}{c}\text { Efficacy } \\
(\%)\end{array}$ & Insect & $\begin{array}{l}\text { Mortality } \\
(\%)\end{array}$ & $\begin{array}{l}\text { Efficacy } \\
\text { (\%) }\end{array}$ \\
\hline Control & 3.6 & 3.4 & --- & --- & 3.4 & --- & --- & 3.6 & --- & --- \\
\hline Desis & 3.2 & 0.6 & 81.3 & 80.2 & 0.4 & 87.5 & 86.8 & 0.2 & 93.8 & 93.8 \\
\hline Megaalpha & 2.6 & 0.8 & 85.7 & 84.7 & 0.3 & 87.3 & 85.9 & 0.41 & 84.1 & 83.2 \\
\hline Alphasin, L & 3.8 & 0.8 & 78.9 & 77.7 & 0.6 & 84.2 & 83.3 & 0.7 & 81.5 & 81.6 \\
\hline Alphasin, $\mathrm{H}$ & 3.6 & 0.6 & 83.3 & 82.3 & 0.4 & 88.9 & 88.2 & 0.5 & 86.1 & 86.1 \\
\hline Control/ULV & 18.3 & --- & --- & --- & 19 & --- & --- & 20 & --- & --- \\
\hline Levo/ULV & 17.3 & --- & --- & --- & 1 & 94.2 & 94.4 & 0.3 & 98.3 & 98.4 \\
\hline Flash, L & 3.1 & 0.6 & 80.6 & 79.5 & 0.4 & 87.1 & 86.3 & 0.3 & 90.3 & 90.3 \\
\hline Flash, H & 3.6 & 0.6 & 83.3 & 82.4 & 0.45 & 87.5 & 86.7 & 0.3 & 90.7 & 91.7 \\
\hline Matrxin plus & 5.0 & 1.1 & 77.3 & 76.0 & 0.98 & 81.3 & 80.0 & 0.8 & 84.0 & 83.1 \\
\hline Golan & 5.1 & 0.9 & 82.4 & 81.3 & 0.5 & 90.2 & 89.6 & 0.3 & 94.1 & 94.1 \\
\hline Talstar, L & 4.1 & 1.7 & 59.5 & 57.1 & 1.6 & 65.1 & 64.2 & 0.5 & 87.2 & 86.0 \\
\hline Talstar, H & 2.6 & 0.8 & 68.3 & 76.0 & 0.6 & 77.7 & 76.5 & 0.2 & 92.0 & 89.8 \\
\hline Bestoy, L & 3.5 & 0.5 & 84.2 & 82.6 & 0.4 & 87.4 & 86.5 & 0.5 & 83.0 & 81.3 \\
\hline Bestoyl, H & 3.2 & 1.05 & 67.2 & 66.0 & 0.4 & 78.1 & 77.5 & 0.3 & 89.7 & 89.0 \\
\hline Bestseller, L & 3.7 & 0.9 & 74.3 & 72.7 & 0.4 & 89.2 & 88.5 & 0.35 & 90.5 & 89.2 \\
\hline Bestseller, H & 4.8 & 0.9 & 80.3 & 78.7 & 0.5 & 89.4 & 88.5 & 0.3 & 90.9 & 90.0 \\
\hline
\end{tabular}

LSD at $0.05=5.1420, \mathrm{~L}=$ low dose, $\mathrm{H}=$ high dose. 
with Alphacypermethrin as active ingredient. In addition using ULV formula (Levo, i. a. oxymatrin) gave the highest efficacy (98.4\%) after one week of treatment in controlling sunn pest individuals.

Therefore, it is recommended that application of insecticide must be timed correctly, targeting the most vulnerable life stage of the insect pest and mixing and applying insecticides carefully. In addition, a key element of effective resistance management is the use of alternation, rotations or sequences of different insecticide mode of action classes. It is important to avoid selecting for resistance or cross resistance by repeated use within the crop cycle, or year after year, of the same insecticide or related products in the same mode of action class, but continues use of pesticides in sunn pest its effect on the environment, reduction of the beneficial fauna, costly human health and environment safety [2].

\section{Conclusions}

It could be concluded from the above illustrated results the availability of some insecticides of different mode of action with high efficacies on sunn pest. Thus, these insecticides were recommended to use in sequence of different mode of action each time during the season, to minimize the chance of resistance selection.

\section{References}

[1] Critchley, B. 1998. "Literature Review of Sunn Pest Eurygaster integriceps Put. (Hemiptera: Scutelleridae).” Crop Protection 17 (4): 271-87.

[2] Moore, D. 1998. "Control of Sun Pests, Particularly Eurygaster integriceps Put. (Hemiptera: Scutelleride): The Role of Mycoinsecticides in Management Schemes.”
In Proceedings of the First Workshop of Integrated Sunn Pest Control, Ankra, Turkey.

[3] El Bouhssini, M., Canhilal, R., and Aw-Hassan, A. 2002. "Integrated Management of Sunn Pest: A Safe Alternative to Chemical Control.” International Center for Agricultural Research in the Dry Areas (ICARDA). Accessed January 23, 2017. http://www.icarda.cgiar.org.

[4] Hariri, G., Williams, P. C., and El-Haramein, F. J. 2000. "Influence of Pentatomid Insect on the Physical Dough Properties and Two Layered Flat Bread Baking Quality of Syrian Wheat.” J. of Cereal Science 31 (2): 111-8.

[5] Gul, A., Akbay, C., and Direk, M. 2006. "Sunn Pest Control Policies and Effect Pest Damage on Wheat Quality and Production in Turkey.” Springer 40 (3): 469-80.

[6] Babaroglu, N., and Kocak, E. 2006. "Evalutaing Insecticides for the Control of Overwintered Adults of Eurygaster integriceps under Field Conditions in Turkey." Phytoparasitica 34 (5): 510-5.

[7] Tarla, G., Poinar, G., and Tarla, S. 2011. "Hexamermis eurygasteri n. sp. (Nematoda: Mermithidae) Parasitizing the Sunn Pest Eurygaster integriceps Puton (Hemiptera: Scutelleridae) in Turkey.” Systemic Parasitology 79 (3): 195-200.

[8] Mutlu, C., Duman, M., Karaca, V., Bayram, Y., Siray, E., and Kan, M. 2016. "A Case Study of Consciousness Level of Farmers in Control of Overwintering Adults Sunn Pest: Southeast Anotolia Region.” Turk. J. Agric. and Natural Sci. 3 (4): 280-7.

[9] Edgington, S., Moore, D., El Bouhssini, M., and Sayyadi, Z. 2007. "Beauveria bassiana for Control of Sunn Pest, Eurygaster integriceps (Hemiptera: Scutelleridae) and Aspects of the Insect's Daily Activity Relevant to a Mycoinsecticide.” Biocontrol Science and Technology 17 (1): 63-79.

[10] Insecticide Resistance Action Committee (IRAC). 2016. IRAC Mode of Action Classification Scheme, Version 8.1. IRAC International MoA Working Group, 26.

[11] Henderson, C. F., and Tilton, E. W. 1955. "Tests with Acaricides against the Brow Wheat Mite." J. Econ. Entomol. 48 (2): 157-61. 